ACTA AGROBOTANICA

Vol. 61 (2): 147-155

2008

\title{
THE EFFECT OF MEDICAGO ARABICA, M. HYBRIDA AND $M$. SATIVA SAPONINS ON THE GROWTH AND DEVELOPMENT OF FUSARIUM OXYSPORUM SCHLECHT F. SP. TULIPAE APT.
}

\author{
Anna Jarecka $^{1}$, Alicja Saniewska ${ }^{1}$, Zbigniew Biały $^{2}$, Marian Jurzysta ${ }^{2}$
}

\begin{abstract}
${ }^{1}$ Research Institute of Pomology and Floriculture 18, 96-100 Skierniewice, Poland, e-mail: asaniew@insad.pl
${ }^{2}$ Department of Biotechnology and Plant Quality, Institute of Soil Science and Plant Cultivation,

Czartoryskich 8, 24-100 Puławy, Poland
\end{abstract}

Received: 7.01.2008

S u m m a r y

In the present work it was shown that total saponins originated from $M$. hybrida and $M$. sativa substantially limited mycelium growth of $F$. oxysporum f. sp. tulipae and symptoms of fusariosis on tulip bulbs. Out of 15 individual tested saponins originated from M. arabica, M. hybrida and M. sativa, four compounds: $3-O-[\beta$-D-glucopyranosyl $(1 \rightarrow 2) \alpha$-L-arabinopyranosyl] hederagenin, hederagenin 3- $O-\beta$-D-glucopyranoside, medicagenic acid, medicagenic acid 3-O- $\beta$-D-glucopyranoside had the strongest inhibitory effect on mycelium growth of Fusarium oxysporum f. sp. tulipae on PDA medium. The total saponins from M. arabica, $M$. hybrida and $M$. sativa inhibited the number of colony forming units of Fusarium oxysporum f. sp. tulipae in artificially infested substrate. The use of saponins originated from Medicago as a fungicide is suggested.

Key words: Medicago arabica, M. hybrida, M. sativa, Fusarium oxysporum f. sp. tulipae, saponins, mycelium growth

\section{INTRODUCTION}

The distribution of saponins in plant kingdom and their biological properties have been recently reviewed by S p a rg et al. (2004). Some saponins have antifungal, antibacterial, antiparasitic, molluscicidal, anti-inflammatory, cytotoxic and antitumor activities. Species of the genus Medicago are a rich source of different saponins with antibacterial and antifungal activities (Avato et al. 2006, Houghton et al. 2006). S a ni ew ska et al. (2001) showed differential antifungal activity of alfalfa (Medicago sativa) total saponins originated from roots and aerial parts for Alternaria zinniae, Botrytis cinerea, Botrytis tulipae, Phoma narcissi, Phoma poolensis and Rhizoctonia solani. Next, it was found that out of ten tested saponins, isolated from the roots and leaves of Medicago sativa, the following four saponins greatly inhibited linear mycelium growth of Botrytis tulipae and Phoma narcissi: 3-O- $\beta$-D-glucopyranoside medicagenate, 3$O$-[ $\beta$-D-glucopyranosyl]-28- $O$-[ $\beta$-D-xylopyranosyl $(1 \rightarrow 4)-\alpha$-L-rhamnopyranosyl $(1 \rightarrow 2)-\alpha$-L-arabinopyranoside] medicagenate, 3-O- $\beta$-D-glucuronopyranosyl$28-O$ - $[\beta$-D-xylopyranosyl $(1 \rightarrow 4)$ - $\alpha$-L-rhamnopyrano$\operatorname{syl}(1 \rightarrow 2)-\alpha$-L-arabinopyranoside] medicagenate and medicagenic acid (Saniewska et al. 2003). Total saponins originated from shoots of Medicago arabica showed antifungal activity in vitro against the following 11 tested taxons of pathogenic fungi: Alternaria alternata, Botrytis cinerea, Botrytis tulipae, Pestalotia spp, Phoma narcissi, Phoma poolensis, Pythium ultimum, Rhizoctonia solani, Fusarium oxysporum f. sp. callistephi, Fusarium oxysporum f. sp. tulipae, Fusarium oxysporum f. sp. narcissi (S a n i e w s k a et al. 2005). The total saponins of Medicago arabica used preventively to treat tulip bulbs inhibited the development of Fusarium oxysporum f. sp. tulipae ( $\mathrm{S}$ a n i e w s k a et al. 2005). Total saponins originated from the roots of Medicago hybrida substantially inhibited mycelium growth of Botrytis cinerea, Botrytis tulipae, Fusarium oxysporum f. sp. callistephi, Fusarium oxysporum f. sp. narcissi, Phoma narcissi ( $\mathrm{S}$ a ni e w ska et al. 2006). Eight individual major saponin glycosides isolated from $M$. hybrida roots were tested for their effect on mycelium growth of Botrytis tulipae and it was documented that hederagenin 3-O- $\beta$-D-glucopyranoside and medicagenic acid 3-O- $\beta$-D-glucopyranoside greatly inhibited the growth of the pathogen (S a ni e w s ka et al. 2006).

In the present study, the effect of total and individual saponins from Medicago arabica, M. hybrida, and M. sativa on growth and development of Fusarium oxysporum f. sp. tulipae is evaluated in vitro and in vivo. 


\section{MATERIALS AND METHODS}

The study was conducted in 2005-2006 at the Research Institute of Pomology and Floriculture in Skierniewice. Four isolates of Fusarium oxysporum f. sp. tulipae, strongly pathogenic to tulip bulbs, were used. cosides

Isolation of total saponins and saponin glu-

Total saponins and their individual glucosides were obtained from the aerial parts of Medicago arabica L. (B i a ł y et al. 2004), and from the roots $M$. of hybrida (Pourret) Trautv. (B i a ł y et al. 2006) and $M$. sativa L. (B i a ły et al. 1999), according to the procedures described in the papers. Shortly afterwards, the ground plant material was defatted with chloroform, and then extracted with methanol under reflux. After removal of alcohol, the residue was dissolved in a small volume of water and the solution was placed on a LiChroprep RP-18 column. The column was washed with water and with diluted methanol until a colourless solution was obtained. Total saponins were eluted with methanol and dried. Then the obtained total saponins were fractionated on a silica gel column by eluting with n-butanol saturated with water, and individual saponin glycosides were separated from the fractions by means of reversed-phase chromatography on LiChroprep RP18 columns eluting with aqueous methanol solutions. Saponin structures were established on the basis of hydrolysis and spectral evidence, including IR, optical rotations, NMR and FAB-MS analyses.

The total saponins and the following saponin glycosides isolated from $M$. arabica, $M$. hybrida and $M$. sativa were studied from the point of view of their effect on growth and development of Fusarium oxysporum f. sp. tulipae:

1. Hederagenin (M. arabica)

2. 3-O-( $\alpha$-L-arabinopyranosyl), 28- $O-(\beta$-D-glucopyranosyl) hederagenin (M. arabica)

3. 3-O-[ $\beta$-D-glucopyranosyl $(1 \rightarrow 2)-\alpha$-L-arabinopyranosyl], 28-O- $\beta$-D-glucopyranosyl hederagenin ( $M$. arabica)

4. 3-O-[ $\beta$-D-glucopyranosyl $(1 \rightarrow 2) \alpha$-L-arabinopyranosyl] hederagenin ( $M$. arabica)

5. Hederagenin 3-O- $\beta$-D-glucopyranoside (M. hybrida)

6. Hederagenin 3-O-[ $\alpha$-L-rhamnopyranosyl $(1 \rightarrow 2)-\beta$ D-glucopyranosyl $(1 \rightarrow 2)$ - $\beta$ - D-glucopyranosyl]-28$O$ - $\beta$-D-glucopyranoside (M. hybrida)

7. Hederagenin 3-O- $\beta$-D-glucuronopyranosyl-28-O- $\beta$ D-glucopyranoside (M. hybrida)

8. Medicagenic acid (M. sativa)

9. Medicagenic acid 3-O- $\beta$-D-glucopyranoside ( $M$. hybrida, M. sativa)
10. Medicagenic acid 3- $O-\beta$-D-glucopyranosyl-28- $O$ $\beta$-D-glucopyranoside (M. hybrida)

11. Medicagenic acid 3-O- $\beta$-D-glucuronopyranosyl28-O- $\beta$-D- glucopyranoside (M. hybrida)

12. 3- $O$-[ $\beta$-D-glucopyranosyl]-28- $O$-[ $\beta$-D -xylopyran$\operatorname{osyl}(1 \rightarrow 4)-\alpha$-L-rhamnopyranosyl $(1 \rightarrow 2)-\alpha$-L-arabinopyranoside] medicagenate ( $M$. sativa)

13. 3-O- $\beta$-D-glucuronopyranosyl-28- $O-[\beta$-D -xylopyranosyl $(1 \rightarrow 4)-\alpha \quad$-L-rhamnopyranosyl $(1 \rightarrow 2)$ $\alpha$-L-arabinopyranoside]medicagenate (M. sativa)

14. $2 \beta, 3 \beta$-dihydroxyolean-12ene-23-al-28-oic acid 3$O-\beta$-D-glucuronopyranosyl- $28-O-\beta$-D-glucopyranoside (M. hybrida)

15. Oleanolic acid 3-O-[ $\beta$-D-glucuronopyranosyl $(1 \rightarrow$ 2)- $\beta$-D-galactopyranosyl]- $28-O-\beta$-D-glucopyranoside (M. hybrida)

In vitro growth of Fusarium oxysporum f. sp. tulipae in the presence of saponins. Four isolates of Fusarium oxysporum f. sp. tulipae (F.ox.t. 17, F.ox. t. 36, F.ox.t. 188 and F.ox.t. 218) were used for the investigations. The total amount of saponins, isolated from Medicago hybrida and M. sativa at final concentrations of $0.01 \% ; 0.05 \%, 0.1 \%$, was previously dissolved in $5 \mathrm{~cm}^{3}$ sterile distilled water and added to potato-dextrose-agar (PDA-Merck) after sterilization at about $50^{\circ} \mathrm{C}$. Single saponins isolated from of Medicago arabica, M. hybrida and $M$. sativa at final concentrations of $8-140 \mu \mathrm{g} \times \mathrm{cm}^{-3}$ were dissolved in $3 \mathrm{~cm}^{3}$ of $75 \%$ methanol and added to $100 \mathrm{~cm}^{3}$ of PDA after sterilization. 5-mm diameter plugs, taken from 7-day-old culture of the tested isolates, were placed in the middle of $90 \mathrm{~mm}$ Petri dishes containing PDA medium supplemented with the tested compounds and the control without saponins. The plates were incubated at $25^{\circ} \mathrm{C}$ in darkness. The diameter of the colonies was measured after 4, 6 and 8 days of incubation, depending on the fungus tested. Five dishes were used for each treatment and the experiment was repeated twice. To analyse the differences between mean values, Duncan's test was used, with a significance level of $\alpha=0.05$.

The influence of saponins on the colony forming units (cfu) of Fusarium oxysporum f. sp. tulipae. Peat-sand (2:1) was artificially infested with F. oxysporum f. sp. tulipae (F.ox.t. 218) using the procedures of T r a m i e r et al. (1983) and O r l i k o w s k i and $\mathrm{S}$ a $\mathrm{n}$ i e w s k a (1988). After two-week incubation of inoculated substrate at $25^{\circ} \mathrm{C}$ in darkness, twenty pots $\left(100 \mathrm{~cm}^{3}\right)$ were filled with $60 \mathrm{~g}$ of inoculated substratum samples (4 x 5 reps). Then, water suspension of total saponins from the used species of Medicago at a concentration $5.0 \%$ was added to the inoculated substrate (three times every 7 days). After 7, 14 and 21 days of incubation of the substratum inoculated and treated with saponins, the population of the pathogen was determined using K o m a d a (1975) medium. The 
inoculated substratum watered only without saponins served as the control. From each sample, $10 \mathrm{~g}$ of soil was taken, diluted with $90 \mathrm{~cm}^{3}$ of sterile distilled water and mixed in a magnetic blender for 30 minutes. One millilitre of the suspension was mixed with $50 \mathrm{~cm}^{3}$ of $\mathrm{Ko} \mathrm{mada} \mathrm{(1975)} \mathrm{medium} \mathrm{at} \mathrm{a} \mathrm{temperature} \mathrm{of} 40$ $-45^{\circ} \mathrm{C}$ and poured into $90 \mathrm{~mm}$ Petri dishes. After a 3day-long incubation of the plates at $25^{\circ} \mathrm{C}$ in the dark and 2-day-long incubation in daylight, the number of $F$. oxysporum f. sp. tulipae colonies was counted as mean values from ten Petri dishes (ø $90 \mathrm{~mm}$ ), and population densities were converted to the number of propagules per gram of air dry soil. The experiment was repeated twice. Duncan's multiple range t-test at 5\% level of significance was used for mean separation.

The effect of total saponins originated from Medicago sativa and M. hybrida on the development of fusariosis on tulip bulbs. 'Apeldoorn' tulip bulbs at the flower bud stage, uncooled, after removal of the first outer scale, were surface disinfected in 50\% ethanol for $5 \mathrm{~min}$., and then rinsed 3 times in sterile distilled water. Then, the bulbs were cut at the basal plate with a cork borer to a depth 1-2 $\mathrm{mm}$ and at a diameter of $3 \mathrm{~mm}$. After cutting the scale, the bulbs were soaked for $60 \mathrm{~min}$. in saponin solutions at concentrations of $0.1 \%$ and $0.5 \%$. Thereafter, $20 \mu \mathrm{l}$ of spore suspension of F.ox.t. 218 with a density of $1.4 \times 10^{6}$ spores $\times \mathrm{cm}^{3}$ of the inoculum was put in the place of the bulb scale damage. The bulbs soaked for $60 \mathrm{~min}$. in distilled water and, inoculated with the suspension of the pathogen spores, were the control. The inoculated bulbs were placed in trays on damp absorbent paper lined with aluminium foil. The trays with the bulbs were put into film bags in order to increase humidity. After 10 days of incubation of the bulbs at a temperature of $25^{\circ} \mathrm{C}$, the length of infection spots was measured.

The comparative fungicide was Sportak Alpha 380 EC (300 g prochloraz $+80 \mathrm{~g}$ carbendazim $\left.\times \mathrm{dm}^{3}\right)$. In each combination, 10 bulbs were tested. The experiments were carried out in two series on the bulbs obtained in the study years.

\section{RESULTS AND DISCUSSION}

In vitro growth of Fusarium oxysporum f. sp. tulipae in the presence of saponins

The total amount of saponins originated from the roots of $M$. hybrida and of alfalfa ( $M$. sativa) at concentrations of $0.01 \%, 0.05 \%$ and $0.1 \%$ showed strong fungitoxic effect against $F$. oxysporum f. sp. tulipae (F.ox.t.). However, there were variable effects on the growth of all the studied isolates. The growth inhibition of F.ox.t. isolates was generally proportional to the concentration of saponins. The linear growth of the mycelium of the tested pathogen isolates, treated with a $0.1 \%$ solution of saponins isolated from $M$. hybrida and M. sativa was inhibited in $73 \%-80 \%$ and $46 \%-69 \%$, respectively, in relation to the control culture (Figs 1, 2). In earlier studies (Saniewska et al. 2005), it was documented that total saponins from $M$. arabica at a concentration of $0.1 \%$ limited the mycelium growth of F.ox.t. 17 in vitro at $63 \%$.

The individual saponin glucosides exerted different effects on the mycelium growth of the isolates of Fusarium oxysporum f. sp. tulipae. Four of them: (4) 3-O-[ $\beta$-D-glucopyranosyl $(1 \rightarrow 2) \alpha$-L-arabinopyranosyl] hederagenin, (5) hederagenin 3-O- $\beta$-D-glucopyranoside, (8) medicagenic acid, (9) medicagenic acid $3-O-\beta$-D-glucopyranoside had the strongest inhibitory influence on the mycelium growth of F.ox.t. on PDA medium (Figs 3,4,5,6). The growth inhibition of the pathogen isolates was generally proportional to the concentration of saponin glucosides (Figs 3, 4, 5 and 6). (1) Hederagenin, (2) 3-O-( $\alpha$ - $L$-arabinopyranosyl), $28-O-(\beta$-D-glucopyranosyl) hederagenin, (3) 3- $O-[\beta$ D-glucopyranosyl $(1 \rightarrow 2)-\alpha$-L-arabinopyranosyl], 28$O-\beta$-D-glucopyranosyl hederagenin, (6) hederagenin 3 - $O$ - $[\alpha$-L-rhamnopyranosyl $(1 \rightarrow 2)-\beta$-D-glucopyrano$\operatorname{syl}(1 \rightarrow 2)-\beta$-D-glucopyranosyl]-28- $O-\beta$-D-glucopyranoside, (7) hederagenin 3-O- $\beta$-D-glucuronopyranosyl-28-O- $\beta$-D-glucopyranoside, (10) medicagenic acid 3-O- $\beta$-D-glucopyranosyl-28- $O-\beta$-D-glucopyranoside, (11) medicagenic acid 3- $O-\beta$-D-glucuronopyranosyl$28-O-\beta$-D-glucopyranoside, (12) 3- $O$ - $[\beta$-D-glucopyranosyl]-28- $O$-[ $\beta$-D-xylopyranosyl $(1 \rightarrow 4)$ - $\alpha$-L-rhamnopyranosyl $(1 \rightarrow 2)$ - $\alpha$-L-arabinopyranoside] medicagenate, (13) 3-O- $\beta$-D-glucuronopyranosyl-28- $O-[\beta$ D-xylopyranosyl $(1 \rightarrow 4)$ - $\alpha$-L-rhamnopyranosyl $(1 \rightarrow 2)$ $\alpha$-L-arabinopyranoside]medicagenate, (15) oleanolic acid $3-O-[\beta$-D-glucuronopyranosyl $(1 \rightarrow 2)-\beta$-D-galactopyranosyl]- 28- $O-\beta$-D-glucopyranoside showed slight fungitoxic activity against mycelium growth of the pathogen (Tab. 1). (14) $2 \beta, 3 \beta$-dihydroxyolean12 ene-23-al-28-oic acid 3-O- $\beta$-D-glucuronopyranosyl- $28-O-\beta$-D-glucopyranoside did not limit but stimulated the growth of the tested pathogen (Table 1). (6) Hederagenin 3-O-[ $\alpha$-L-rhamnopyranosyl $(1 \rightarrow$ 2)- $\beta$-D-glucopyranosyl $(1 \rightarrow 2)-\beta$ - D-glucopyranosyl]$28-O-\beta$-D-glucopyranoside, (7) hederagenin $3-O-\beta$ D-glucuronopyranosyl-28- $O-\beta$-D-glucopyranoside, (10) medicagenic acid 3-O- $\beta$-D-glucopyranosyl-28$O-\beta$-D-glucopyranoside, (11) medicagenic acid 3-O$\beta$-D-glucuronopyranosyl-28- $O-\beta$-D- glucopyranoside, slightly stimulated mycelium growth of $F$. oxysporum f. sp. tulipae at low concentrations and showed slight fungitoxic activity at higher concentrations (Tab. 1). The individual saponins from Medicago which greatly inhibited mycelium growth of $F$. oxysporum f. sp. tulipae were also most active against other pathogens of ornamental plants (S a n i e w s k a et al. 2003, 2006). 
Table 1

The effect of individual saponins indicated in Material and Methods as number 1, 2, 3, 6, 10, 11, 12, 13, 14 and 15 on the mycelium growth of Fusarium oxysporum f. sp. tulipae (F. ox. t. 17) after eight days of incubation (\% of control).

\begin{tabular}{|c|c|c|c|c|c|c|c|c|c|c|c|}
\hline $\begin{array}{c}\text { Conc. } \\
\mu \mathrm{g} \times \mathrm{cm}^{-3}\end{array}$ & $\begin{array}{c}\text { Saponin } \\
\mathbf{1}\end{array}$ & $\begin{array}{l}\text { Saponin } \\
2\end{array}$ & $\begin{array}{c}\text { Saponin } \\
\mathbf{3}\end{array}$ & $\begin{array}{c}\text { Saponin } \\
\mathbf{6}\end{array}$ & $\begin{array}{c}\text { Saponin } \\
7\end{array}$ & $\begin{array}{c}\text { Saponin } \\
\mathbf{1 0}\end{array}$ & $\begin{array}{c}\text { Saponin } \\
11\end{array}$ & $\begin{array}{c}\text { Saponin } \\
\mathbf{1 2}\end{array}$ & $\begin{array}{c}\text { Saponin } \\
\mathbf{1 3}\end{array}$ & $\begin{array}{c}\text { Saponin } \\
\mathbf{1 4}\end{array}$ & $\begin{array}{c}\text { Saponin } \\
\mathbf{1 5}\end{array}$ \\
\hline 10 & -13.6 & -6.4 & -0.8 & +2.3 & +19.5 & -2.3 & -1.2 & -7.7 & -2.0 & +24.3 & -13.5 \\
\hline 25 & -24.5 & -17.5 & -7.2 & -6.2 & +16.5 & +0.5 & +0.2 & -8.3 & -7.1 & +18.8 & -25.3 \\
\hline 50 & -26.6 & -16.0 & -11.6 & -1.6 & -20.3 & -4.8 & -6.0 & -9.5 & -10.5 & +8.5 & -30.4 \\
\hline 140 & -31.2 & -29.6 & -14.3 & -7.0 & -24.6 & -5.6 & -1.2 & -25.5 & -37.5 & +2.7 & -15.4 \\
\hline
\end{tabular}

“+”- stimulatory effect ,“_“- inhibitory effect

Table 2

Influence of saponin solutions on colony forming units (cfu) of F. oxysporum f. sp. tulipae.

\begin{tabular}{lccc}
\hline & \multicolumn{2}{c}{ Number of cfu/gram of air dry soil after days of incubation } \\
\cline { 2 - 4 } & $7(1 \mathrm{st}-$ treatment $)$ & $14(2 \mathrm{nd}-$ treatment $)$ & $21(3 \mathrm{rd}-$ treatment $)$ \\
\hline Control & $8539 \mathrm{~d}$ & $5579 \mathrm{~d}$ & $3684 \mathrm{~d}$ \\
M. arabica $5.0 \%$ & $5278 \mathrm{c}$ & $1052 \mathrm{~b}$ & $1388 \mathrm{~b}$ \\
M. hybrida $5.0 \%$ & $1677 \mathrm{~b}$ & $1777 \mathrm{c}$ & $2217 \mathrm{c}$ \\
M. sativa $5.0 \%$ & $0,0 \mathrm{a}$ & $179 \mathrm{a}$ & $279 \mathrm{a}$ \\
\hline
\end{tabular}

Means in colums followed by the same letters are not significantly different at $\mathrm{P}=0.05$ according to Duncan's test.

Table 3

Effect of preventively used saponins on the development of fusariosis on tulip bulbs cv. Apeldoorn.

\begin{tabular}{lccc}
\hline & Necrosis diameter $(\mathrm{mm})$ & Depth of necrosis (mm) & $\begin{array}{c}\text { Presence }(+) \text { or } \\
\text { absence }(-) \text { of gum }\end{array}$ \\
\hline Control & $18.9 \mathrm{c}$ & $6.4 \mathrm{c}$ & $(+)$ \\
\hline Saponins from $M$. hybrida & & & $(-)$ \\
$0.1 \%$ & $3.2 \mathrm{~b}$ & $1.0 \mathrm{~b}$ & $(-)$ \\
$0.5 \%$ & $0.0 \mathrm{a}$ & $0.0 \mathrm{a}$ & $(-)$ \\
\hline Saponins from $M$. sativa & & & $(-)$ \\
\hline $0.1 \%$ & $3.2 \mathrm{~b}$ & $1.0 \mathrm{~b}$ & $0.0 \mathrm{a}$ \\
\hline Prochloraz + carbendazim (Sportak Alpha & $0.0 \mathrm{a}$ & & $(-)$ \\
\hline 80 EC) & & $0.0 \mathrm{a}$ & \\
\hline
\end{tabular}

See Table 2 


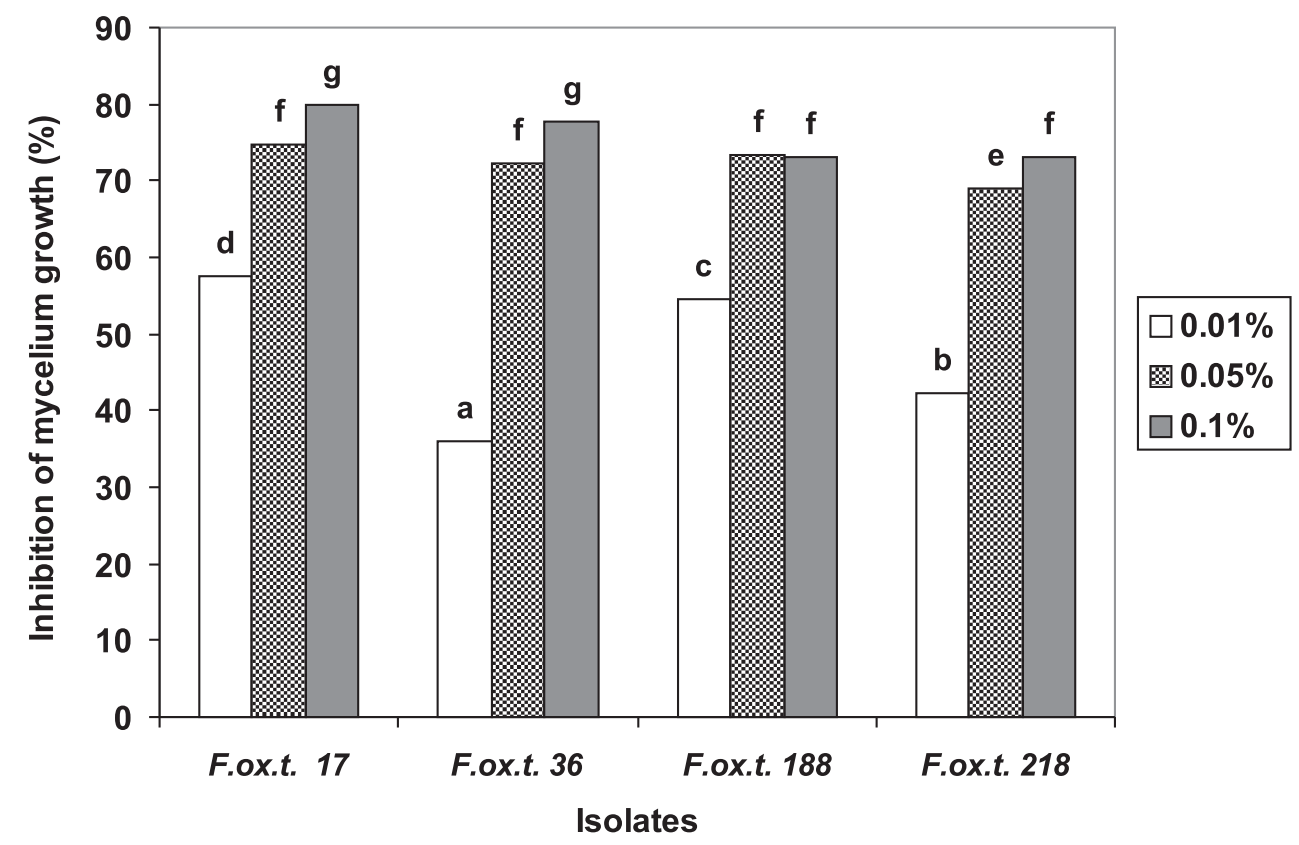

Fig. 1. Inhibitory effect of total saponins originated from roots of Medicago hybrida on in vitro mycelium growth of four isolates of Fusarium oxysporum f. sp. tulipae (F.ox.t. 17, F.ox.t. 36, F. ox.t. 188, F.ox.t. 218) after eight days of incubation; means followed by the same letters are not significantly different at $\mathrm{P}=0.05$ according to Duncan's test.

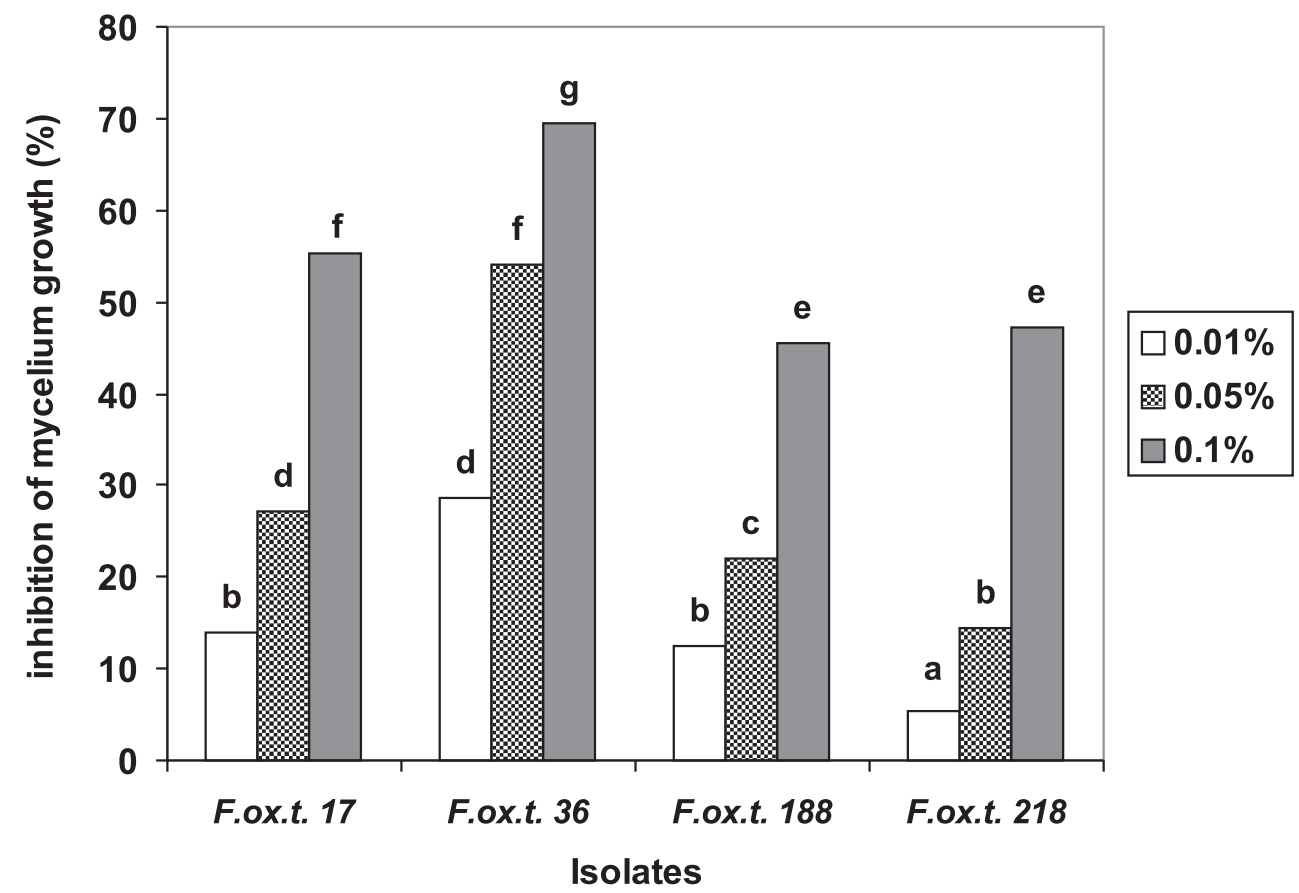

Fig. 2. Inhibitory effect of total saponins originated from roots of Medicago sativa on in vitro mycelium growth of four isolates of Fusarium oxysporum f. sp. tulipae (F.ox.t. 17, F.ox.t. 36, F. ox.t. 188, F.ox.t. 218) after eight days of incubation; means followed by the same letters for each isolate are not significantly different at $\mathrm{P}=0.05$ according to Duncan's test. 


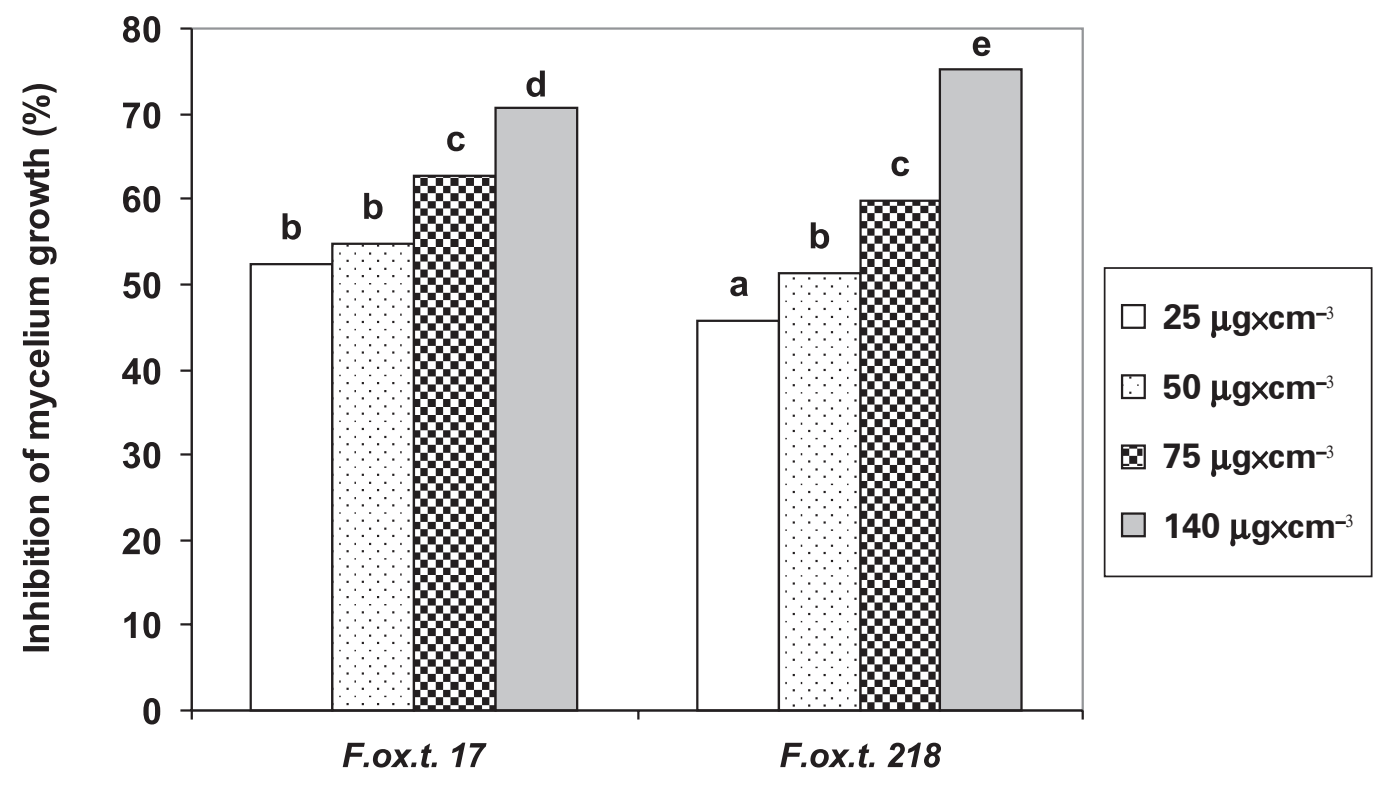

Concentration in $\mu \mathrm{g} \times \mathrm{cm}^{-3}$

Fig. 3. Inhibitory effect of (4) 3-O-[ $\beta$-D-glucopyranosyl $(1 \rightarrow 2) \alpha$-L-arabinopyranosyl] hederagenin at different concentrations on in vitro mycelium growth of two isolates of Fusarium oxysporum f. sp. tulipae (F. ox. t. 17 and F.ox. t. 218) after 8 days of incubation.

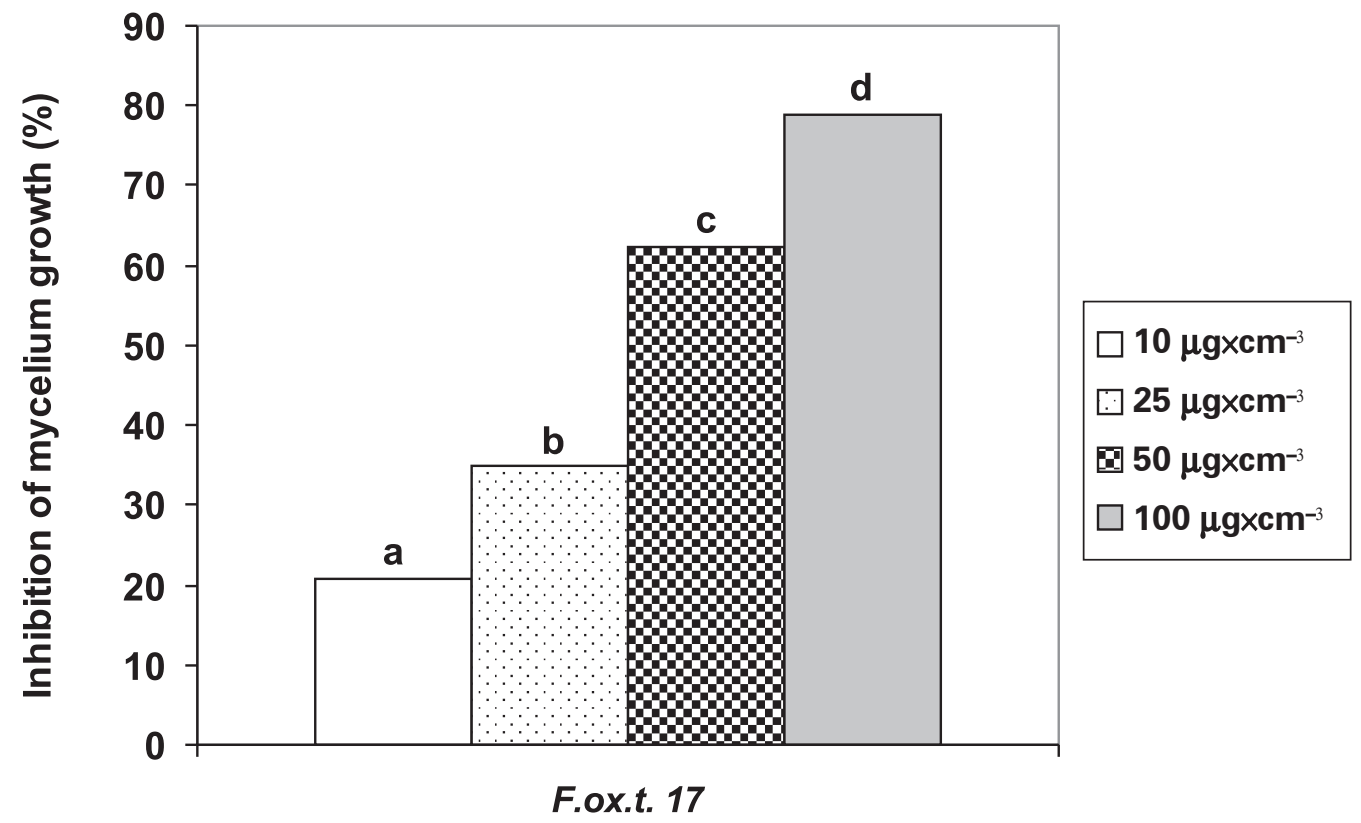

Concentration in $\mu \mathrm{g} \times \mathrm{cm}^{-3}$

Fig. 4. Inhibitory effect of (5) hederagenin 3-O- $\beta$-D-glucopyranoside at different concentrations on in vitro mycelium growth of Fusarium oxysporum f. sp. tulipae (F. ox.t. 17) after 6 days of incubation. 


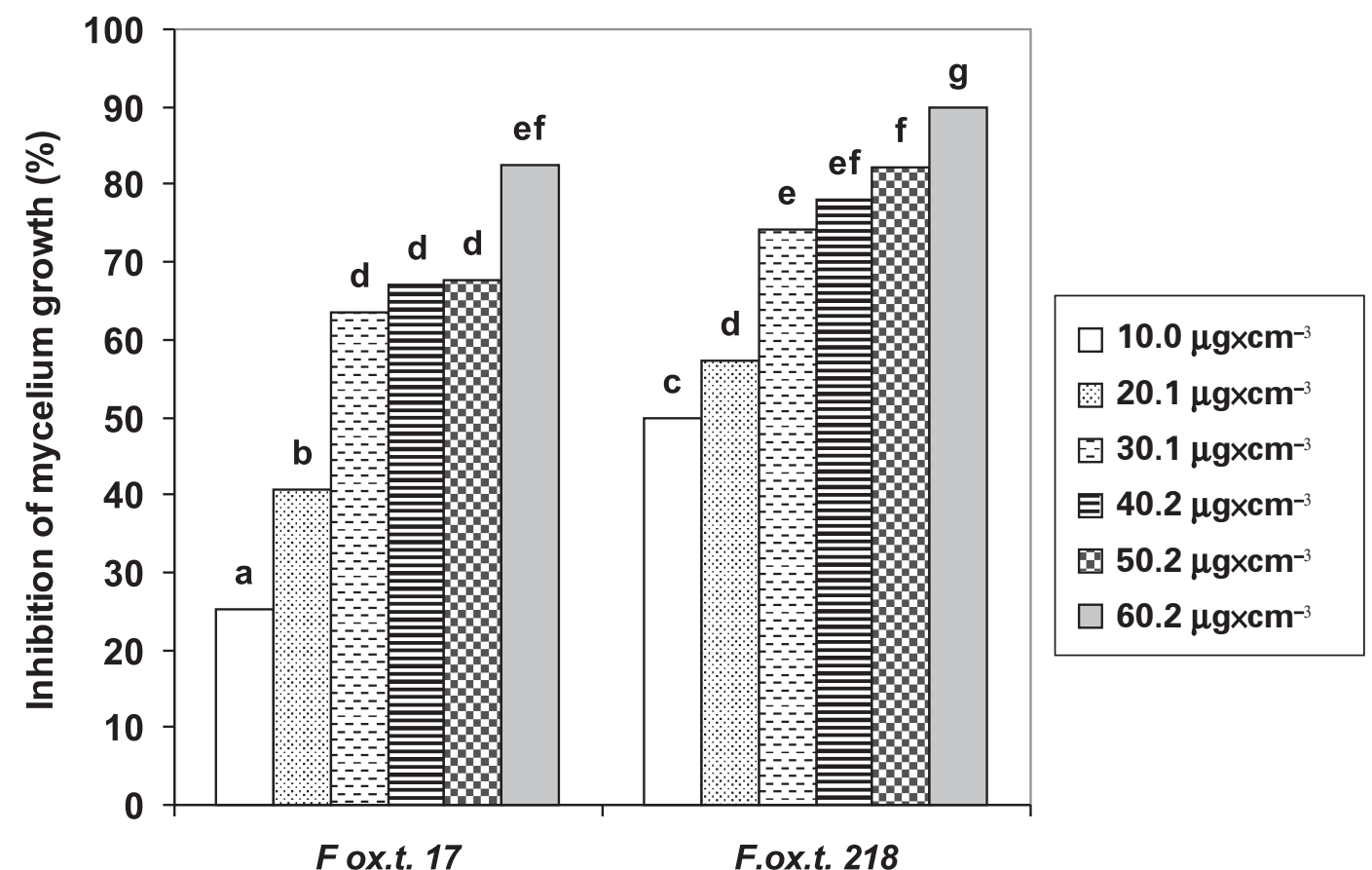

Concentration in $\mu \mathrm{g} \times \mathrm{cm}^{-3}$

Fig. 5. Inhibitory effect of (8) medicagenic acid at different concentrations on in vitro mycelium growth of two isolates of Fusarium oxysporum f. sp. tulipae (F. ox. t. 17 and F.ox.t. 218) after 8 days of incubation.

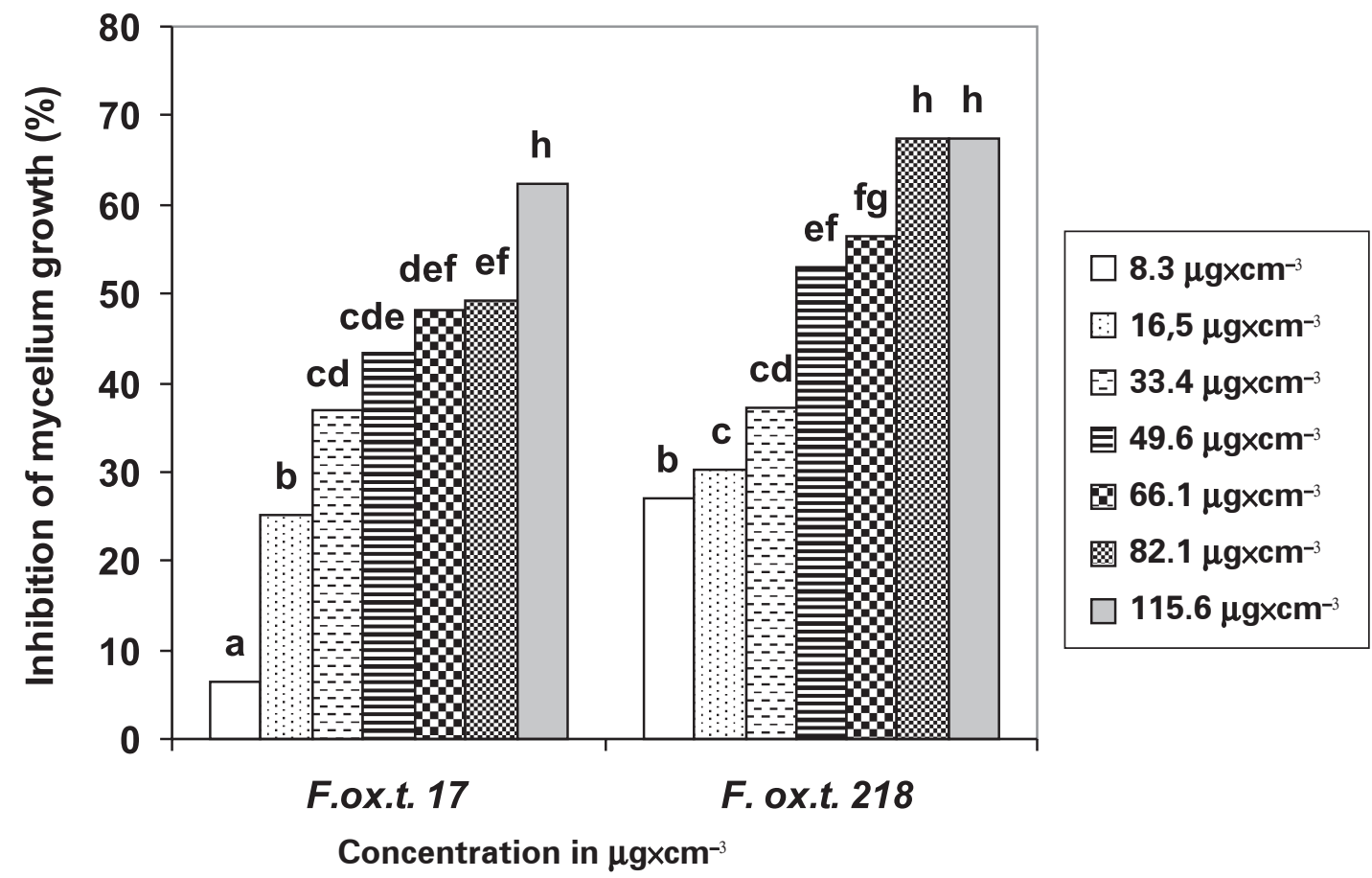

Fig. 6. Inhibitory effect of (9) medicagenic acid 3-O- $\beta$-D-glucopyranoside at different concentrations on in vitro mycelium growth of two isolates of Fusarium oxysporum f. sp. tulipae (F. ox. t. 17 and F.ox.t. 218) after 8 days of incubation. 
The influence of saponins on colony forming units (cfu) of Fusarium oxysporum f. sp. tulipae

The total saponins from M. arabica, M. hybrida and M. sativa decreased the number of colony forming units (cfu) of Fusarium oxysporum f. sp. tulipae in artificially infested substrate. However, there were variable effects on cfu of the tested saponins of different species of Medicago. The total saponins used at a concentration of $5.0 \%$ reduced the number of cfu of the pathogen of M. sativa in $92.5 \%, \mathrm{M}$. arabica in $60 \%$ and $\mathrm{M}$. hybrida in $40 \%$, in comparison to the control substrate without saponins (Tab. 2). It is the first report that saponins of Medicago decrease the number of colony forming units of Fusarium oxysporum f. sp. tulipae in substrate.

The effect of total saponins from Medicago sativa and $M$. hybrida on the development of fusariosis on tulip bulbs

Total saponins from $M$. hybrida and M. sativa used preventively to treat tulip bulbs, inhibited the development of F. oxysporum f. sp. tulipae (Tab. 3). The size of necrosis on the surface of scale of bulbs was smaller, being totally inhibited at a concentration of $0.1 \%$, like in the case of prochloraz + carbendazim (Sportak Alpha 380 EC). Disease development was not observed in internal tissues or with a minimum increase during the incubation of the bulbs in comparison with the control bulbs which were not treated. The control bulbs showed the development of the mycelium and gummosis in the area of inoculation. Such sings of development of the mycelium of the pathogen were not observed on the bulbs treated with the saponis solution. Similar results, concerning the limitation of disease symptoms caused by Fusarium oxysporum f. sp. tulipae on tulip bulbs, were documented earlier for saponins isolated from Medicago arabica (S a n i ew s ka et al. 2005). It is suggested that saponins of these three species of Medicago which showed considerable fungitoxic activity against Fusarium oxysporum $\mathrm{f}$. sp. tulipae may be used as a natural fungicide for limiting the spread of the pathogen on tulip bulbs.

\section{REFERENCES}

Avato P., Bucci R., Tava A., Vitali C., Rosato A., Biały Z., Jurzysta M., 2006. Antimicrobial activity of saponins from Medicago sp.: structure-activity relationship. Phytother. Res. 20: 454-457.

Biały Z., Jurzysta M., Mella M., Tava A., 2004. Triterpene saponins from aerial parts of Medicago arabica L. J. Agric. Food Chem. 52: 1095-1099.

Biały Z., Jurzysta M., Mella M., Tava A., 2006. Triterpene saponins from the roots of Medicago hybrida. J. Agric. Food Chem. 54: 2520-2526.
Biały Z., Jurzysta M., Oleszek W., Piacente S., Pizza C., 1999. Saponins in alfalfa (Medicago sativa L.) root and their structural elucidation. J. Agric. Food Chem. 47: 3185-3192.

Houghton P., Patel N., Jurzysta M., Biały Z., Cheung C., 2006. Antidermatophyte activity of Medicago extracts and contained saponins and their structure-activity relationship. Phytother. Res. 20: 1061-1066.

Komada H., 1975. Development of selective medium for quantitative isolation of Fusarium oxysporum from natural soil. Rev. Pl. Prot. Res. 8: 114-125.

Orlikowski L. B., Saniewska A.,1988. Influence of some environmental factors on the population density of $F u$ sarium oxysporum f. sp. callistephi in soil. Pr. Inst. Sad. i Kwiac. Ser. B12: 177-188.

Saniewska A., Biały Z., Jurzysta M., 2003. The effect of alfalfa (Medicago sativa) saponins on Botrytis tulipae and Phoma narcissi growth. Phytopathol. Pol. 27: 15-27.

Saniewska A., Jarecka A., Biały Z., Jurzysta M., 2005. Antifungal activity of saponins from Medicago arabica L. shoots against some pathogens. Allelopathy Journal, 16: 105-112.

Saniewska A., Jarecka A., Biały Z., Jurzysta M., 2006. Antifungal activity of saponins originated from Medicago hybrida against some ornamental plant pathogens. Acta Agrobot. 59: 51-58.

Saniewska A., Jurzysta B., Biały Z., 2001. Differential antifungal activity of alfalfa (Medicago sativa L.) saponins originated from roots and aerial parts for some ornamental plant pathogens. Acta Agrobot. 54: 31-43.

Sparg S. G., Light M. E., van Staden J., 2004. Biological activities and distribution of plant saponins. J. Ethnopharmacol. 94: 219-243.

Tramier R., Pionnat J. C., Tobibel N., 1983. Role of the fungi in the induction of suppressiveness into substrates to Fusarium wilt of carnation. Acta Hort. 141: 55-59.

\section{Oddziaływanie saponin z Medicago arabica, $M$. hybrida i $M$. sativa na wzrost i rozwój Fusarium oxysporum f. sp. tulipae}

\section{Streszczenie}

Wykazano, że suma saponin pozyskana z korzeni Medicago hybrida i M. sativa w stężeniach 0,01\%, $0,05 \%$ i $0,1 \%$ oddziaływała fungitoksycznie na wzrost grzybni 4 izolatów Fusarium oxysporum f. sp. tulipae (F.ox.t.) w warunkach in vitro na pożywce PDA. Najwyższe stężenie saponin $(0,1 \%)$ najsilniej ograniczało wzrost grzybni badanych izolatów F.ox.t.; inhibicja wynosiła w granicach $73-80 \%$ dla saponin izolowanych z $M$. hybrida i 46-65\% dla saponin z $M$. sativa.

Spośród badanych 15 poszczególnych pojedyńczych saponin otrzymanych z $M$. arabica, $M$. hybrida i $M$. sativa 4 następujące saponiny wykazały silne ha- 
mujące działanie na wzrost grzybni izolatów F.ox.t: 3$O$-[ $\beta$-D-glukopiranozylo $(1 \rightarrow 2) \alpha$-L-arabinopiranozyd $]$ hederageniny (M. arabica) - w stężeniu $140 \mu \mathrm{gxcm}^{-3}$ $70 \%$ hamowanie, 3-O- $\beta$-D-glukopiranozyd hederageniny ( $M$. hybrida) - w stężeniu $100 \mu \mathrm{gxcm}^{-3} 80 \%$ hamowanie, kwas medikagenowy ( $M$. sativa) - w stężeniu $60 \mu \mathrm{gxcm}^{-3} 85 \%$ hamowanie, $3-O-\beta$-D-glukopiranozyd kwasu medikagenowego ( $M$. hybrida, $M$. sati$v a)$ - w stężeniu $115 \mu \mathrm{gxcm}^{-3} 65 \%$ hamowanie.

Suma saponin pozyskana z M. hybrida i $M$. sativa zastosowana profilaktycznie do zaprawiania cebul tulipana silnie ograniczała rozwój fuzariozy. W stężeniu $0,1 \%$ suma saponin z każdego badanego gatunku lucerny ograniczała rozwój choroby w około $80 \%$, oceniany długością i głębokością plam infekcyjnych i hamowała tworzenie się gum. Zastosowane sumy saponin w wyższym stężeniu $0,5 \%$ silniej ograniczały rozwój patogena.

Badane sumy saponin, zastosowane w stężeniu 5\%, do podlewania zakażonego przez F.ox.t. 218 podłoża, wykazały inhibicyjny, jednakże zróżnicowany wpływ na rozwój patogena w podłożu. Najsilniej ograniczała liczbę jednostek tworzących kolonie F.ox. t 218, suma saponin z $M$. sativa (około 92\%), słabsze wyniszczające oddziaływanie na patogena wykazała M. hybrida (około 60\%) a najsłabiej ograniczała rozwój patogena suma saponin z M. arabica (około 40\%) - w porównaniu do liczebności jednostek tworzących kolonie F.ox.t. 218 w podłożu kontrolnym nie traktowanym. 